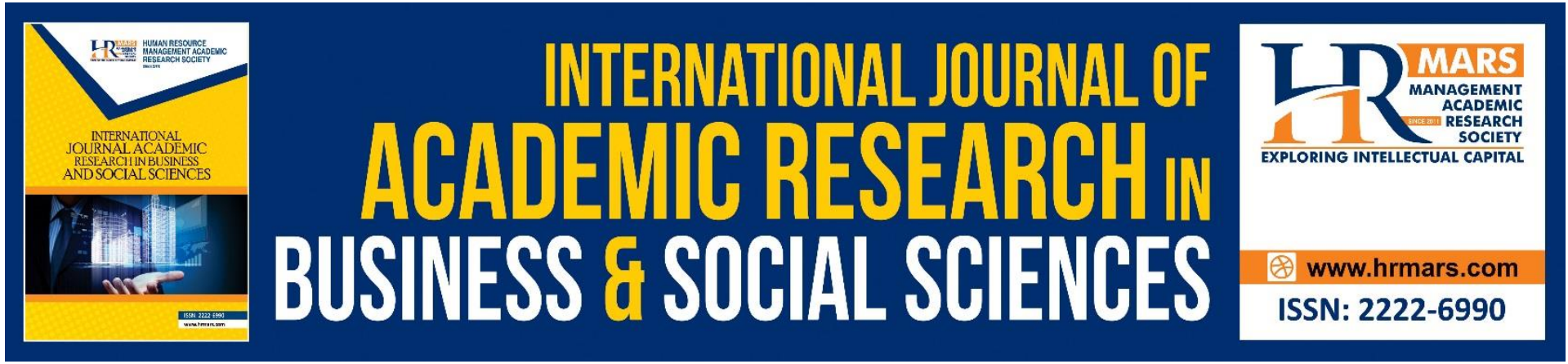

\title{
Malay Cultural Heritage in Selected Science Fiction Novels
}

Rosnani Md Zain, Nik Rafidah Nik Muhamad Affendi, Kamariah Kamarudin, Salmah Jan Noor Muhammad

To Link this Article: http://dx.doi.org/10.6007/IJARBSS/v11-i8/10255

DOI:10.6007/IJARBSS/v11-i8/10255

Received: 13 June 2021, Revised: 16 July 2021, Accepted: 31 July 2021

Published Online: 19 August 2021

In-Text Citation: (Zain et al., 2021)

To Cite this Article: Zain, R. M., Affendi, N. R. N. M., Kamarudin, K., \& Muhammad, S. J. N. (2021). Malay Cultural Heritage in Selected Science Fiction Novels. International Journal of Academic Research in Business and Social Sciences, 11(8), 1678-1688.

\section{Copyright: (c) 2021 The Author(s)}

Published by Human Resource Management Academic Research Society (www.hrmars.com)

This article is published under the Creative Commons Attribution (CC BY 4.0) license. Anyone may reproduce, distribute, translate and create derivative works of this article (for both commercial and non-commercial purposes), subject to full attribution to the original publication and authors. The full terms of this license may be seen at: http://creativecommons.org/licences/by/4.0/legalcode

Vol. 11, No. 8, 2021, Pg. 1678 - 1688

Full Terms \& Conditions of access and use can be found at http://hrmars.com/index.php/pages/detail/publication-ethics 


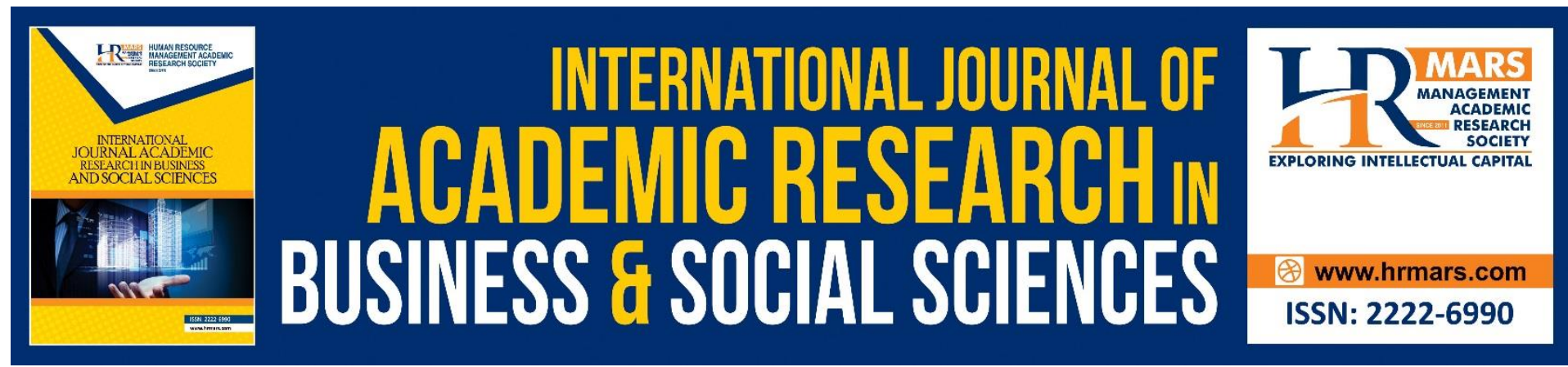

\title{
Malay Cultural Heritage in Selected Science Fiction Novels
}

\author{
Rosnani Md Zain, Nik Rafidah Nik Muhamad Affendi, Kamariah \\ Kamarudin, Salmah Jan Noor Muhammad \\ Department of Malay Language, Faculty of Modern Languages and Communication \\ Universiti Putra Malaysia, 43400 Serdang, Selangor
}

\begin{abstract}
This paper discusses the Malay cultural heritage found in science and technology- fiction novels, namely Detik (2012), Kronikel Etanol (2015) and Klon (2015). In short, the Malay cultural heritage refers to a practice or way of life inherited from generation to generation and is still practiced by the young generation today. This study was conducted based on the opinion of academics, who pointed out that science fiction and technology-based novels accordingly displays the culture of Malay heritage. With that, this study will focus on two objectives that are, to classify and analyze the Malay cultural heritage found in the aforementioned novels that are studied on. Qualitative research method and text analysis as well as the application of Teori Warisan are used as the theoretical foundation in this study. The result of this study found that the Malay cultural heritage includes procedures the life of the Malay community is based on the family system and social system. Both of these institutions are a symbol of the Malay cultural heritage.
\end{abstract}

Keywords: Malay Cultural Heritage, Science Fiction, Teori Warisan, Family, Community

\section{Introduction}

The novel is one of the creative works that belong to the genre of prose that reveals the life of society from various dimensions. One of the aspects in the life of society that is often raised in a literary work such as a novel is culture. According to Wan (1988), culture is a learned human behavior and is symbolic, and a human reaction to the adaptation of life to the environment. Culture, scientifically, defined as a way of life in the form of the birth of a society's heritage, whether it is a material or not a material. The culture also encompasses all aspects of life such as knowledge, beliefs, arts, laws, ethics, and customs (Aziz, 2005). Based on that opinion, culture can be understood as a way for society to continue to survive. The culture can also be categorized into two forms, material culture and non - material culture. Both forms of this culture finally gave birth to the Malay community that has a way of life that distinguishes it with other cultures in Malaysia. Back to the question, the importance of the implementation of cultural elements in literary works that it has a close relationship with the original function of literary industry itself, namely as a means of disseminating knowledge, and at the same time, serves as entertainment to the reader. In this case, the literary work of science fiction and technology-based novels is not excluding carrying out the important role 
in displaying the Malay culture to the reading community. This is in line with the opinion of Ahmad Zaki (2015) that science and technology fiction novels are not just flying saucers, space adventures, aliens, and robots only, it is actually more to a combination of exploring in the realm of mystery fiction, action, fantasy, detective and technology in a piece of writing which contains Malay cultural heritage. This statement clearly gives a firsthand display that science and technology fiction novels have an important role in revealing the Malay culture to readers. Thus, this study will examine the Malay cultural heritage found in the novels of science fiction that are Detik (2012), Kronikel Etanol (2015) and Klon (2015).

\section{Research Objectives}

- To classify the Malay cultural heritage found in the selected science fiction novels

- To analyze the Malay cultural heritage found in the selected science fiction novels

\section{Literature Review}

Preliminary observations have been several scientific studies that discuss the Malay cultural heritage and science fiction novels. Among them is a study conducted by Maizir and Tengku (2017), entitled Warisan Budaya Melayu dalam Novel Sri Rahayu sebagai Medium Pendidikan. The study found that the Malay cultural heritage in the form of poetry, courtesy and history is an aspect that is emphasized as a medium of education to the readers. Although this study examines the elements of culture, the study does not use science and technology fiction novels as research materials.

In addition, previous studies on science and technology fiction novels are also highlighted by the researcher. A previous study found by Rosnani and Rafidah (2019) entitled Unsur Sains dan Sastera dalam novel remaja terpilih. This study used two science and technology teen novels, Tawanan Komander Caucasus (2010) by Ruzaini Yahya and Di Sebalik Dinara (2012) by Dayang Noor. This study found that both teen novels highlighted the elements of science, that are applied science and zoology science. While the literary elements showed the aspects of moral values, thoughts, emotions and language styles.

Next, Rosnani and Rafidah (2019) also discussed science and technology fiction novels through a scientific study entitled Unsur Estetika Bahasa dalam Novel-Novel Pemenang Sayembara Fiksyen Sains dan Teknologi dari Tahun 2012 Sehingga 2017. This scientific study only focuses on aesthetic aspects of language which is the use of language styles such as proverbs, metaphors, personifications, similes, assonances and anaphors. Based on the literature review on the Malay cultural heritage in the novels, the researcher found that there were no previous studies that examine the science and technology fiction novels in addressing these aspects. While scientific studies that are using science and technology fiction novels, they did not discuss the aspects of Malay cultural heritage. Past studies that were examined found that only scientific elements and language style elements were performed by previous researchers. Past research clearly shows that there is a reasonable gap in the study done by analyzing the Malay Cultural Heritage in Selected Science and Technology Fiction Novels.

\section{Research Methodology}

In this study, the researcher used two research methods, library research and text analysis. For the text analysis method, this study used Teori Warisan to strengthen the researcher's statements. This theory was introduced A.Wahab in 2013 which is based on the initial idea 
that the living practices and culture of a community or ethnic group, whether it is known or not, are part of the past cultural heritage of that community or ethnic group. According to $A$. Wahab (2013), the theory that was produced has four basic concepts that are accepting inheritance, rejecting and leaving inheritance, changing and adding and continuous inheritance. The first concept which is receiving an inheritance refers to a community that lived at a certain time is the heir of its community. The community practices the customs of its community in daily life. The community is the heir of its past community. They have the right to practice the culture of their community. As part of culture, literature is also inherited from generation to generation and undergoes a process as experienced by the culture of a community, tribe or civilization. This is because, literature is a reflection of the society. For the second concept, a community that lives in a certain era has the right to reject or leave its cultural heritage. Rejecting or abandoning an inherited cultural practice of the community is in accordance with the collective demands of its community. The third concept is that a community has the right to change and add to its community's heritage for the sake of survival, sustainability and the development of its community's culture and civilization. The fourth concept refers to the heritage itself has a continuous concept. "Continuous" means that the heritage received at one time, will be passed on to the next generation. Inherited cultural heritage will undergo a process of either retention, rejection, change or addition. A community that inherits the culture of that community will consider the elements of culture, whether it wants to accept and maintain it, change, add or create a new one. This is in accordance with the importance of the current society that inherited a culture. Thus, a community's culture has traditions, while continuing to dynamically build new traditions in its community's civilization. With that, all four of these theoretical concepts are appropriate to examine the cultural elements contained in the works of Malay literature.

\section{Analysis and Discussion of the Study Malay Cultural Heritage in Families}

According to Fatimah (2015), a family is always referred to as a social group that lives together, manages the economy together, and performs reproductive functions besides educating children. A family usually consists of a married couple along with one or more of their children, including adopted children. Zainal (2008) stated that the Malays are very concerned about the family ties that each individual can be associated with the relation by blood, marriage, descent, the adopted with a person will be considered as 'relatives'. Even wider and farther, the family is still a 'tribe'. Only those who cannot relate to any new relationship are considered 'other people' or distant relatives, there is still a distant relationship. This perspective is clearly pointed out that the Malay community has a strong sense of kinship systems that have become part of their cultural heritage.

Malay culture emphasizes the aspects of harmony in marriage. The wife is like a reflection of the husband's behavior. Therefore, the husband plays a very important role in guiding and educating the wife so that the pride in the household is always preserved and be followed by the children.

Hence, the Malay cultural heritage of maintaining harmony in the household can be detected in the novel, Detik (2012) by Amir Husaini. The situation is shown through the positive relationship between Mrs. Fiqriyah and her husband who is described as a wife who is full of love, responsible and concerned about the health of her husband, Prof. Dr. Sa'at Ahkeer. As 
a wife who loves her husband, Fiqriyah always advises her husband to take care of his health and not do strenuous activities because his husband has heart complications. This can be proved through the following passages:

"That's why honey, I have reminded you a lot of times to take of your health. Do not do activities that are too strenuous. You don't always exercise, and suddenly you are running promptly to chase people, so without a doubt, there must be complications," said his wife while nagging.

(Detik: 6)

In relation to that, Hussin and Mohd (1997) stated that a wife should not ignore the needs of her husband or ignore his requests. The more often a wife cares about her husband, the more the husband loves her. Most husbands believe that the caring attitude of wives is an expression of their love for their husbands. This clearly shows that the attitude of Mrs. Fiqriyah is the best example of a wife who is an agent of a harmonious family in the community as a symbol of Malay cultural heritage.

In addition, the Malay culture also encourages the attitude of love in the family. Love is the most important element in shaping children's identity. Children who receive love and full of attention from their parents will give birth to a spiritually and physically balanced generation. In the novel Klon (2015) by Idris Boi, he displayed the effects of receiving true love from parents has given birth to an excellent human being, Dr. Fakiruddin. The character of Dr. Fakiruddin described as a young Malay who has education in science and technology and works in the United States, but he has the love in him because he never forgets the kindness and sacrifice of his parents in providing the best education to him. The situation can be seen in the passage below:

The love for his father and mother never fades. To him, they are everything. Without them, he wouldn't be in a good place right now. Father and mother have sacrificied a lot for him. Their kindness were so great that he could not repay them, even with piles of wealth.

(Klon: 337)

The value of love and responsibility towards the family is in line with the opinion of Asmad (1990) who asserted that the foundation of the family begins at home. Parents feel responsible for the lives and happiness of their children. Children, on the other hand, feel responsible to their parents, especially elderly parents. Thus, such family ties are fundamental in the formation of the family system in the Malay community that has become a heritage for generations.

Furthermore, the Malay family system also prioritize education to children. According to Mohd (2007), the Malay community carries out an education culture that starts from the womb until the children receive formal education in schools. It is marked by various customs and taboos practiced by the Malays such as a child can not be wrapped, but given freedom. Preferably, the child should sleep in a prone position, not in a supine position. During birth, the Malay community also encourages mothers to breastfeed their babies. This is because, the Malays believed that breast milk is the best milk instead of cow's milk. From customs and 
taboos inherited from generation to generation, this has given birth to a Malay community that prioritized the aspects of education to children.

As a result, the exposure of the Malay culture that emphasizes education to children clearly highlighted in the novel, Kronikel Etanol (2015) by Hafizul Osman. In the novel, the author applied the perfect education received has given birth to a useful human being to the nation and country, namely Dr. Majmin. This is clearly seen in the following passage of the novel Kronikel Etanol $(2015,11)$, 'Min should be grateful for the upbringing of father and mother, making Min a useful individual to the community and the country'.

In the Malay community, parents must have a sense of responsibility towards their children by providing the perfect education and teaching so that children will not be the individuals who lost their sense of life and do not have a direction in life when they grow up (Yaakub, 1991). In relation to that, the Malay culture in the family system that emphasizes love and education values to children in line with Teori Warisan as described by A. Wahab (2013) that the people who live in an era is the heir of their community. The people practiced the customs of their community in their daily lives. They are the rightful heirs receiving the inheritance of their community. Therefore, the Malays in the modern epoch are also entitled to maintain, preserve and take care of the love and education values to maintain harmony in the household as a legacy of the Malay race.

\section{Malay Cultural Heritage in the Community The Hospitality Culture}

The Malays are known to honor their guests. Every guest who visits the house will receive good hospitality. This culture of hospitality is recognized by the western scholar, Laurent (2007) who visited the Peninsula in the 19th century who stated that "Hospitality is one of the Malay virtues". This fact clearly shows that the Malays have an attitude that likes receiving guests. Thus, this culture is instilled in the community since they were little. This can be seen in the novel, Detik (2012) by Amir Husaini went throught the portrayal of the character Awwal who understands that guests must be celebrated and welcomed well. This noble gesture will form a good personality in children. Therefore, the child will understand that entertaining guests was one of Malay cultures and the demands in the teachings of Islam. The situation can be explained through the passage below:

It's going to be alright, mother. Let's just start this ceremony. All of Awwal's friends are waiting. It's not nice if we let our guests waiting", the little boy composed his words that sounded mature.

(Detik:32)

In relation to that, it is true as what Robiah (1993) said that the main foundation of the formation of a child's noble personality starts from home. Parents need to be the best role models for children, because they are the people closest to the children. Everything that is done will be followed, good behavior or vice versa. The culture of honoring guests is in line with the Teori Warisan by A.Wahab (2013) that explains that heritage itself has a continuous concept. "Continuous" means that the heritage of a community in an era will be inherited by the next generation. 
The culture of hospitality can also be seen through the novel Klon (2015). The author, Idris Boi, focused on the character of the Malays in entertaining guests. This is clearly seen through the character of Dr. Fakiruddin who treated the FBI officers, who questioned him like a criminal, well. However, Dr. Fakiruddin did not act rudely but treated them well even those who came uninvited.

"Important? What is the issue? What has that got to do with my career?" urged Dr. Fakiruddin who wanted to know. The FBI members looked at each other. Actually, Dr. Fakiruddin was not happy with the way the members spoke to him. As if he is like an actual criminal. Even though he is a manager at this company.

(Klon:75)

In the novel of the same authors, it also showed the kindness of Malays in accepting strangers into their family. This can be identified through the character of the mother and father of Dr. Fakiruddin who welcomed Dr. Susan Lancaster as a guest. The good treatment from Dr. Fakiruddin's parents caused Dr. Susan Lancaster felt like she was in her own family. This can be proved through the following passages:

The way Haji Maimunah Ali and her husband including Dr. Fakiruddin's family treated Dr. Susan Lancaster nicely made her feel as if she was with her own family members.

(Klon:377)

Based on the examples of the passages in the novel, the culture of honoring guests is in line with the Teori Warisan by A. Wahab (2013) that explained that heritage itself has a continuous concept. "Continuous" means that the heritage of a community in an era will be inherited by the next generation of the community. The culture of entertaining guests that is inherited for generations has been the practice in the community even though in this modern epoch, the world is chasing to advance science and technology. Accordingly, it can be emphasized that the practice has been deeply entrenched in the Malay community.

\section{The Culture of Helping Each Other}

The culture of helping each other is also surrounded by the author's thinking in science fiction novels. Helping each other is the attitude of helping and supporting each other. Helping each other can be done according to the situation, the willingness that can be fulfilled includes helping in terms of property and helping in terms of time (Harun, 2003). The culture of helping each other can be seen in the novel Klon (2015) by Idris Boi through the depiction of the character of a married couple who saved Klon H1A from being arrested by the FBI. This situation can be shown on page 196 which reads, "Once again thank you for helping me", he said. The old woman just smiled. Soon, an old man, who was the old woman's husband, came to find Klon $H 1 A^{\prime}$.

This culture of helping each other can also be traced in the novel Detik (2012) by Amir Husaini that described the character of Zaki and Rezuan who helped Prof. Dr. Sa'at Akheer who was found unconscious in the backyard of his house. As neighbors, they carried out that 
responsibility by helping people in distress. This is also what Mustafa (1999) emphasized that in any society, the practice of neighborliness is a norm and universal phenomenon. In fact, the unity of a community can be measured through the high and low quality of life of neighboring practices. This attitude can also foster a spirit of unity among the community, as in the quote 'Fortunately, the young men who rented next to our house saw my black brother. Zaki and Rezuan who helped my brother to walk back home '(Detik: 6). The culture also coincided with the opinion of Harun (2003) who stressed that the emphasis on the aspect of unity is in line with the will of Islam which wants the people to live together, work together and strengthen brotherhood and help each other in the matters of goodness. Islam also calls on the people to stay away from all forms of debilitating strifes. In relation to that, the culture of helping each other as highlighted in the novel Detik and Klon is in line with the Teori Warisan by A. Wahab (2013) that a community living at a certain time has the right to reject or leave its cultural heritage. Rejecting or abandoning a cultural practice of the inherited community, is appropriate with the collective demands of its community. Thus, the culture of helping each culture is one that still remains practiced and accepted in the Malay community.

\section{The Culture of Attire}

Basically, the clothes a person wears are to cover the aurat and serve as protection from hot and cold weather. The ethics of dressing up can be detected in the novel, Kronikel Etanol (2015) by Hafizul Osman that displayed the dress code of Malay women through the character Dr. Kamalia who was described as dressed modestly with a shariah -compliant hijab and loose shirt which can be seen in the quote, "This girl is wearing a loose blouse and a fully covered hijab. The hijab was slightly attached to cover the chest before being pinned to her left shoulder" (Kronikel Etanol: 25).

Meanwhile, in the novel Klon (2015) by Idris Boi, he highlighted the manners of wearing appropriately which was described through the character of Dr. Susan Lancaster. For example, Dr. Susan was introduced with polite manners and culture of Malay women's attire which refers to the baju kurung batik canting, the traditional attire of the Malays and wearing a headscarf as a claim in Islam. This is clearly illustrated through the passage below:

\section{Dr. Susan Lancaster smiled. She looked so sad and beautiful wearing a modernized purple-colored baju kurung carved with bunga cempaka merah. The hand drawn baju kurung batik was a custom order by Hajah Maimunah Ali for Dr. Susan Lancaster on that historic day. With a light blue headscarf from a fine type of fabric. One glance does not change like a princess from heaven.}

(Klon: 379)

The situation is in line with the Teori Warisan, founded by A. Wahab (2013) that a community has the right to change or add to its community's heritage for survival, sustainability and development of its community's culture and civilization. In this case, this can be attributed to that the culture of wearing modestly and covering their aurat began when the community accepts Islam and rejects animism and Hindu-Buddhist. In relation to that, the culture of wearing modest attire and cover their aurat to be one of the cultural heritage of the civilized Malay community and show the identity of a society who is very concerned about faith in God. 


\section{Language Culture}

The community has been exposed about the manners and civility since childhood. Even the Malays who are not civilized and polite are considered 'rude' or 'less civilized' and the worst of all are the 'barbaric, cowardly and treacherous' (Hashim, 2008).

Politeness is the practice of behavior that obeys the social rules that exist in a society. Someone who does not abide by these social rules is considered rude. According Yaakub (1991), the Malays were educated properly on the family level to create a generation of that has rules and conform to all ethics of community. For example, in the novel Klon (2015) by Idris Boi, the character of Dr. Fakiruddin as a person who is very careful when communicating even to uninvited guests who are rude to him. This is clearly shown in the passage below:

"Please sit down", Dr. Fakiruddin invited as he tried to be polite. That is the core of the community's civilization. He is a Malay who is rich in politeness. Even though he works in a foreign land, his culture and courtesy are still maintained. Wherever he is, he follows the traditions and culture from where he came from.

(Klon:71)

The Malay culture through the politeness of language can also be traced in the novel Kronikel Etanol (2015) by Hafizul Osman. This situation can be seen throught the character of Kamalia who relized her words hurted Majmin's feelings, then she apologized. This can be proved in the passage below:

"Forgive me! I have no intention to hurt you. That is just my assumption, maybe you are not like that", said Kamalia trying to ease the tension after they were silent for a long time.

(Kronikel Etanol: 29)

Similarly, in the novel Detik (2012) by Amir Husaini, he highlighted the Malay culture of politeness when speaking. This situation can be seen through the character Prof. Dr. Sa'at Akheer who feels guilty for ruining the feelings of his son, Awwal. As a father, he doesn't want the conflict to carry on till it jeopardises the harmony of their family. He tried to persuade Awwal and apologize for not being able to go home to celebrate his son's birthday. Thus, the manners and decency are highly prioritized by the Malay community not only in the aspects of doing, but also the important thing is the speech or language (Nor Hashimah, 2005). This can be proved the passage below:

He tried to ease the cold atmosphere. "Awwal, I'm sorry."

(Detik: 134)

In relation to that, Zaitul (2009) stated that everyone should prioritize the norms of being polite when communicating based on the cultural background behind it. This statement gives emphasis that being polite when speaking are highly demanded in the Malay culture, even the aspect of it has been given emphasis in the teachings of Islam. Plus, it can also been seen 
that being polite in speaking that is carried out by Malay community that has been shown in all three novels, in accordance to Teori Warisan by A. Wahab (2013). It said that the heritage itself has a continuous concept. "Continuous" means that the heritage of a community in one era will be inherited by the next generation of the community. Thus, it can be affirmed that the practice has been deeply rooted in the Malay community.

\section{Conclusion}

Based on a discussion analysis, it clearly showed that the science fiction novels displayed the customs of the Malay community's lives or the culture that is carried out by the Malay community. This is clearly shown through the practice carried out by the Malay community who are still maintaining the way of life in a family system. This culture can be seen through a positive family system among the family members. The Malay culture can also been seen throught the social system that has become the traditional practices, the politeness of speaking and wearing attire, which are the epitome of Malays. Other than that, the culture of helping each other and entertaining guests are still maintained in the social system of the Malay community. The culture of helping each other and entertaining guests are the dominant cultures in the novels that were studied. This is clearly denoted that the cultures are paramount in creating harmony and unity in the social system of the Malay community. With that, it can be concluded that the science and technology-fiction novels, Klon (2015), Kronikel Etanol (2015) and Detik (2012) are still maintaining the Malay culture. The novel that were studied can also proved that the science fiction genre not only highlights the advancement of science and technology, but also the culture of the Malay community that has become a priority to local science fiction novel authors. Thus,

the findings have made a significant contribution on the study of modern Malay literature especially in science fiction novel that can be studied from multiple dimensions.

\section{Reference}

Aziz, A. D. (2005). Asas Pemikiran Kebudayaan Malaysia. Kuala Lumpur: Dewan Bahasa dan Pustaka.

Wahab, A. (2013). Konsep Teori Warisan. Dewan Sastera, 37-43.

Ahmad. Z. A. B. (2015). Peranan Penulis Fiksyen Sains dan Teknologi. In Saleeh, R. \& Rozlan M, N. (ed), Sastera Teras Negara Bangsa. (pp.395-405), Kuala Lumpur: Institut Terjemahan dan Buku Malaysia.

Amir, H. (2012). Detik. Kuala Lumpur: Utusan Publications \& Distributions Sdn Bhd.

Asmad. (1990). Kebudayaan Secara Umum. Melaka: Associated Educational Distribution.

Fatimah, A. (2015). Keluarga dan Permodenan di Malaysia. Kuala Lumpur: PTS Publications Hafizul, O. (2015). Kronikel Etanol. Kuala Lumpur: Utusan Publications \& Distributions Sdn Bhd.

Harun, A. T. (2003). Akhlak Harian Setiap Muslim. Kuala Lumpur: Al-Hidayah Publish.

Hashim, M. (2008). Hati Budi Melayu Pengukuhan Menghadapi Cabaran Abad Ke-21. Penerbit: Universiti Putra Malaysia.

Hussin, S., Mohd, N. R. (1997). Adab Sopan dan Pekerti dalam Islam. Kuala Lumpur: Universiti Teknologi Malaysia Skudai.

Idris, B. (2015). Klon. Kuala Lumpur: Utusan Publications \& Distributions Sdn Bhd.

Laurent, M. (2007). Nilai-Nilai Melayu: Satu Sudut Pandangan Orang Luar. Tanjong Malim: Universiti Pendidikan Sultan Idris. 
Maizira, A. M., Tengku, I. M. (2017, May 24-25). Warisan Budaya Melayu dalam Novel Sri Rahayu Sebagai Medium Pendidikan. Persidangan Antarabangsa Pengajian Kemanusiaan, Kota Kinabalu.

Mohd, Y. H. (2007). Teori Pendidikan Pemikiran Global. Tanjong Malim: Universiti Pendidikan Sultan Idris.

Mustafa, D. (1999). Tamadun Islam. Kuala Lumpur: Utusan Publications \& Distibutors Sdn. Bhd.

Hashimah, N. J. (2005). Sistem Panggilan Keluarga Melayu: Satu Dokumentasi. Kuala Lumpur: Dewan Bahasa dan Pustaka.

Robiah, K. H. (1993). Remaja dan Pengurusan Diri. Kuala Lumpur: Dewan Bahasa dan Pustaka. Rosnani, M. Z., Rafidah, N. (2019). Unsur Sains dan Sastera dalam novel remaja terpilih. PENDETA Journal of Malay Language, Education and Literature: 10. 166-182.

Rosnani, M. Z., Rafidah, N. (2019.) Unsur Estetika Bahasa Dalam Novel-Novel Pemenang Sayembara Fiksyen Sains Dan Teknologi Dari Tahun 2012 Sehingga 2017. Manu: 30. 189212.

Yaakub, H. (1991). Keluarga Melayu Bandar: Satu Analisis Perubahan. Kuala Lumpur:Dewan Bahasa dan Pustaka.

Wan, A. K. (1988). Budaya Popular dalam Masyarakat Melayu Bandaran. Kuala Lumpur: Dewan Bahasa dan Pustaka, Kementerian Pendidikan Malaysia.

Zainal, K. (2008). Minda Melayu: Suatu Tafsiran. In Anwar, R. Minda Melayu (pp.17-61). Kuala Lumpur: Dewan Bahasa dan Pustaka.

Zaitul, A. Z. H. (2009). Konsep Masa Dalam Perbualan Remaja: Jurnal Persatuan Linguistik 9. 153-163. 